\title{
Water Quality and Eutrophication in Jatiluhur Reservoir, West Java, Indonesia
}

\author{
Lismining Pujiyani Astuti*, Yayuk Sugianti, Andri Warsa, Agus Arifin Sentosa \\ Research Institute for Fish Resource Enhancement, Ministry of Marine Affairs and Fisheries Republic of Indonesia, \\ Jalan Cilalawi No. 1, Jatiluhur, Purwakarta, West Java, Indonesia 41152
}

Received: 8 April 2021

Accepted: 21 September 2021

\begin{abstract}
The eutrophication in Jatiluhur Reservoir had continued due to organic pollution. The high eutrophication negatively impacted reservoir sustainability and some activities there, such as fisheries. This study aimed to determine the level of eutrophication and provide some alternative recommendations for its control. The research was conducted by sampling method in 2017 on nine representing stations. A stratified sampling method took samples of water and phytoplankton. The results showed that based on the TSI index value $(>4)$, Trix index $(>50)$, the eutrophication status of the Jatiluhur reservoir was in eutrophic-hypertrophic level. Some alternative control which could recommend were: (1) utilizing macrophyte as a nutrient absorbing agent, (2) stocking of planktivorous fish, and (3) implementing an environmental friendly of fish culture in floating cage system.
\end{abstract}

Keywords: eutrophication, TSI, TRIX, eutrophic-hypertrophic, Jatiluhur Reservoir

\section{Introduction}

Eutrophication is the enrichment of nutrients, especially phosphate and nitrogen. Its characterized by excessive growth of phytoplankton and aquatic plants, causing decreased water quality in lakes, reservoirs, ponds, and other water ecosystems $[1 ; 2]$. Eutrophied waters are characterized by low dissolved oxygen and high phytoplankton biomass, reducing the use-value of water [3]. Eutrophication occurs due to organic pollution, resulting in disturbances in the ecological balance [1].

Jatiluhur Reservoir, which has the official name Ir. H. Djuanda Reservoir, is located in Purwakarta Regency, West Java, Indonesia. The reservoir, which located at $110 \mathrm{~m}$ above sea level, dams the Citarum

e-mail: lisminingastuti@gmail.com
River. Its function is irrigation, flood control, power generation, water sources for home and industry, tourism, sports, and fisheries, both capturing fisheries and aquaculture [4]. The input of organic and nonorganic pollutants from rivers into reservoirs, land use, aquaculture activities, and tourism impacts eutrophication. Intensive aquaculture by floating net cages can cause eutrophication caused by inefficient feedings, such as uneaten feed and fish excretion. This activity will increase nitrogen and phosphate concentrations, especially in sediments [5]. The sedimentation rate of the Jatiluhur Reservoir catchment area was about $6,22 \mathrm{~m}^{3} / \mathrm{ha} / \mathrm{yr}$ or $190,313.26 \mathrm{~m}^{3} / \mathrm{yr}$ [45].

In 1988, Jatiluhur Reservoir had mesotrophic levels based on primary productivity [6]. In 2006, its status increased to hypertrophic based on nitrogen and phosphorus nutrients [7]. In 2017, the loading of phosphor pollution to Jatiluhur Reservoir reached $13.474,4$ tons/yr, which came from internal and external 
sources [46]. In this study, the determination of eutrophication level used the Carlson Trophic State Index (TSI), which based on the parameters of transparency, total phosphorus and chlorophyll-a [8], and the Trix index, which based on the parameters of chlorophyll a, nitrogen, phosphorus, and oxygen saturation [9]. Based on the eutrophication level obtained, alternative control can be determined and recommended. This study aimed to determine the conditions of eutrophication level and alternative control recommendations in Jatiluhur Reservoir.

\section{Material and Methods}

\section{Study Area}

This research was conducted in 2017 in Jatiluhur Reservoir. The reservoir is located at latitude $06^{\circ} 25^{\prime}$ $06^{\circ} 35^{\prime} \mathrm{S}$ and longitude $107^{\circ} 22^{\prime}-107^{\circ} 30^{\prime} \mathrm{E}$. The Jatiluhur reservoir has a total area of about 8300 ha. This reservoir is a cascade reservoir that dams the Citarum River after Saguling reservoir and Cirata reservoir.

\section{Sampling Station}

Water samples were collected from nine sampling stations, namely as inlet Citarum River (ST 1), riverine

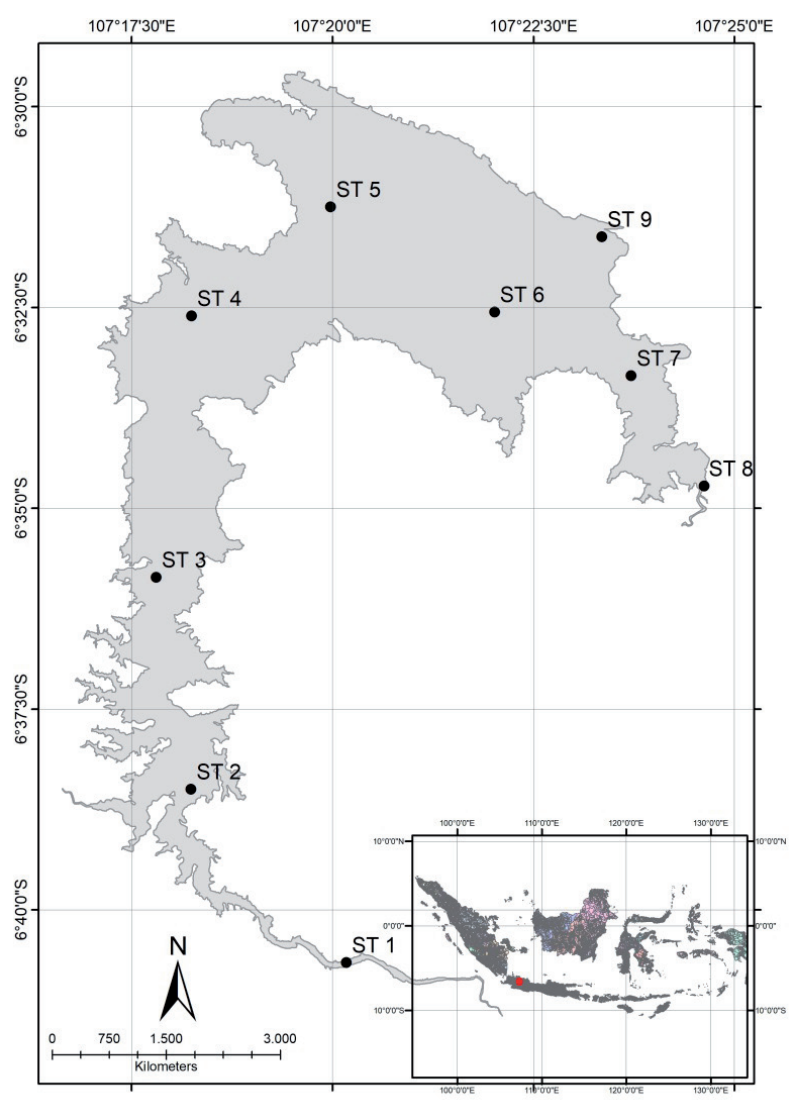

Fig 1. The sampling stations in the Jatiluhur reservoir. zona (ST 2 and ST 3), floating cage culture zone (ST 4, ST 5, ST 6, and ST 7), an inlet from Cilalawi River (ST 8) and Dam or outlet (ST 9). In nine stations, which represent for inlet (riverine zone), floating cage zone, and outlet (near to DAM) (Fig. 1).

\section{Sample Collection}

Water samples were collected from 9 sampling stations from February, March, August, September, and October 2017. February represented the rainy season, March represented the transition of rain to dry season, August and September represented the dry season, and October represented the transition of dry to the rainy season.

To take the water and plankton samples by Kemmerer Water Sampler from stratified depth, i.e., surface, 4 and $8 \mathrm{~m}$. Water samples put in bottle sampler. The analysis methods and instruments for measuring the observed parameters were presented in Table 1.

We used plankton net no. 25 (mesh size $60 \mathrm{~m}$ ) to collect plankton samples at depths of 0,4 , and $8 \mathrm{~m}$. The plankton samples were then kept in a $25 \mathrm{ml}$ sample container with a 1 percent Lugol's solution. Using a binocular microscope at a magnification of $100 \mathrm{x}$, observations were made on 20 fields of view. The phytoplankton identification references utilized were from several available manual identifications [10-13].

\section{The Eutrophication Level}

The eutrophication level was assessed based on the Carlson Trophic state index (TSI) and the Trix index. Determination of the Carlson index is carried out by Carlson's equation which was dependent on the parameters of Chlorophyll-a, total phosphorus [8]:

$$
\begin{gathered}
\text { TSI-SD }=60-14.41 * \ln [\mathrm{SD}] \\
\text { TSI-TP }=4.15+14.42 * \ln [\mathrm{TP}] \\
\text { TSI-Chl }=30.6+9.81 * \ln [\mathrm{Chl}] \\
\text { TSI }=(\text { TSI-SD }+ \text { TSI-TP }+ \text { TSI-Chl }) / 3
\end{gathered}
$$

where SD was the value of transparency (m), TP was the concentration of total phosphorous $(\mu \mathrm{g} / \mathrm{l})$, and $\mathrm{Chl}$ was the concentration of Chlorophyll-a $(\mu \mathrm{g} / \mathrm{l})$.

The TRIX index was calculated based on Chlorophyll-a's parameters, the percentage of saturated dissolved oxygen (\% DO), DIN (Dissolved Inorganic Nitrogen), and orthophosphate, and a value scale ranged from $0-10$.

$$
O_{2 \text { sat }(\%)}=\frac{O_{2} \text { measure }}{O_{2} \text { saturation }} \times 100 \%
$$

The saturation of dissolved oxygen was calculated to depend on water temperature, as suggested by [14]:

$$
O_{2 \text { sat }}=0.035 T^{2}-0.3369 T+14.407
$$


Table 1. The analysis methods and instruments for measuring the observed parameters.

\begin{tabular}{|c|c|c|c|}
\hline No & Parameters & Units & Methods/Instruments \\
\hline 1 & Water Temperature & ${ }^{\circ} \mathrm{C}$ & Water Quality Checker/YSI Multi parameters \\
\hline 2 & Transparency & $\mathrm{cm}$ & Secchi disc \\
\hline 3 & Dissolved Oxygen & $\mathrm{mg} / 1$ & Water Quality Checker/YSI Multi parameters \\
\hline 4 & Orthophosphate & $\mathrm{mg} / 1$ & SNI 06-6989.31-2005/Spectrophotometry \\
\hline 5 & Total Phosphorus & $\mu \mathrm{g} / 1$ & Ascorbate Acid / Spectrophotometry \\
\hline 6 & Nitrate & $\mathrm{mg} / 1$ & Brucinesulphate / Spectrophotometry \\
\hline 7 & Nitrite & $\mathrm{mg} / 1$ & SNI.06-6989-72-2009/ Spectrophotometry \\
\hline 8 & Chlorophyll-a & $\mu \mathrm{g} / 1$ & Trichromatic \\
\hline 9 & BOD $_{5}$ & $\mathrm{mg} / 1$ & Winkler \\
\hline
\end{tabular}

where $\mathrm{O}_{2}$ sat (\%) was the percentage of the oxygen saturation $(\%), \mathrm{O}_{2 \text { sat }}$ was the oxygen saturation $(\mathrm{mg} / \mathrm{l})$, and $\mathrm{T}$ was the water temperature $\left({ }^{\circ} \mathrm{C}\right)$.

The DIN value was the sum of $\mathrm{NH}_{4}^{+}, \mathrm{NO}_{3}$, and $\mathrm{NO}_{2}$. Eutrophication level using Trix index was a linear combination from four variables: chlorophyll-a, saturation oxygen, nitrogen, and phosphorus. A Trix index value closed to 10 indicated the eutrophic level, while if it closed to 0 indicated the oligotrophic (Table 2). The Trix index could be used to evaluate long-term eutrophication levels in waters [15].

$$
\operatorname{Trix}=\frac{k}{n} \sum_{i}^{n} \frac{(\log M-\log L)}{(\log U-\log L)}
$$

where $\mathrm{k}$ was scaling factor $(=10)$, $\mathrm{n}$ was the number of parameters $(=4)$, U was the upper limits value, L was the lower limits value and $\mathrm{M}$ was the average of the parameters.

\section{Phytoplankton Abundance}

The calculation of phytoplankton's cell abundance was carried out using the Lackey Drop Microtransect Counting Chamber method with the following equation:

$$
N=n \times \frac{A}{B} \times \frac{C}{D} \times \frac{1}{E}
$$

where $\mathrm{N}$ was the phytoplankton abundance (cell/1), $\mathrm{n}$ was the average total number of individuals per field of view, A was the area of glass cover $\left(\mathrm{mm}^{2}\right)$, B was the area of a field of view $\left(\mathrm{mm}^{2}\right), \mathrm{C}$ was the volume of concentrate water $(\mathrm{ml}), \mathrm{D}$ was the volume of one drop water $(\mathrm{ml})$ under the cover glass, and $\mathrm{E}$ was the volume of filtered water (1).

Low phytoplankton abundance $(<30,000$ cells/l) was a criterion for oligotrophic waters, whereas high phytoplankton abundance (30,000-100,000 cells/1) was a mesotrophic waters, and a high phytoplankton abundance $(>100,000$ cells/1) was a eutrophic waters [16].

\section{Results and Discussion}

\section{Physicochemical Water Quality Parameters}

The monitoring of water quality was collecting information on water quality in many places at regular intervals to provide data used to determine current conditions, determine trends in water quality according to usage standards, and as a basis for future policy recommendations [17]. Water quality monitoring in Jatiluhur Reservoir was carried out to monitor water quality changes, the biota's key. Water quality played a vital role in aquatic life, such as fish, benthos, molluscs, and aquatic plants. The suitable water quality would support various uses in that reservoir.

Table 2. The assessment of eutrophication level based on the Carlson and the Trix index.

\begin{tabular}{|c|c|c|c|}
\hline No & Carlson Trophic state index (TSI) & Indeks Trix & Status \\
\hline 1 & $<30-40$ & $<2$ & Oligotrophic \\
\hline 2 & $40-50$ & $2 \leq$ trix $\leq 4$ & Eutrophic \\
\hline 3 & $50-70$ & $4 \leq$ trix $\leq 6$ & Hypertrophic \\
\hline 4 & $70->100$ & Trix $\geq 6$ & \\
\hline
\end{tabular}


Table 3. The water temperature and transparency in Jatiluhur Resevoir on 2017.

\begin{tabular}{|c|c|c|c|c|c|c|c|c|c|c|}
\hline Month & Parameters & ST 1 & ST 2 & ST 3 & ST 4 & ST 5 & ST 6 & ST 7 & ST 8 & ST 9 \\
\hline \multirow{3}{*}{ February } & Transparancy $(\mathrm{cm})$ & 130 & 10 & 100 & 160 & 130 & - & 200 & 70 & 150 \\
\cline { 2 - 11 } & Water temperature $\left({ }^{\circ} \mathrm{C}\right)$ & 25 & 27.4 & 26.6 & 26.7 & 26.9 & - & 27.9 & 28.27 & 26.9 \\
\hline \multirow{3}{*}{ March } & Transparancy $(\mathrm{cm})$ & 90 & 130 & 150 & 120 & 160 & 105 & 150 & - & 120 \\
\cline { 2 - 11 } & Water temperature $\left({ }^{\circ} \mathrm{C}\right)$ & 26.1 & 27.9 & 28.7 & 28.8 & 28.4 & 29.3 & 29.4 & 29 & 29.3 \\
\hline \multirow{3}{*}{ August } & Transparancy $(\mathrm{cm})$ & 160 & - & 150 & 140 & 140 & 100 & 130 & - & 110 \\
\cline { 2 - 11 } & Water temperature $\left({ }^{\circ} \mathrm{C}\right)$ & 27.0 & 27.3 & 29.3 & 28.9 & 28.7 & 29.3 & 29.2 & 26.8 & 28.6 \\
\hline \multirow{3}{*}{ September } & Transparancy $(\mathrm{cm})$ & 50 & - & 100 & 140 & 125 & 100.5 & 120 & 30 & 130 \\
\cline { 2 - 10 } & Water temperature $\left({ }^{\circ} \mathrm{C}\right)$ & 28.7 & 28.1 & 29.7 & 29.3 & 29.3 & 29.6 & 29.7 & 32.7 & 28.8 \\
\hline \multirow{2}{*}{ October } & Transparancy $(\mathrm{cm})$ & 30 & 20 & 90 & 85 & 130 & 90 & 150 & 60 & 100 \\
\cline { 2 - 10 } & Water temperature $\left({ }^{\circ} \mathrm{C}\right)$ & 27.7 & 27.7 & 29.2 & 30.2 & 29.2 & 29.9 & 29.9 & 32.2 & 29.7 \\
\hline
\end{tabular}

Note: Standard of water temperature is $25-35^{\circ} \mathrm{C}$ based on second class quality standards of Government Regulation No. 82 Year 2001; Stardard of transparancy for tilapia is $45-50 \mathrm{~cm}$ [23]

The water temperature ranged from $25-32.7^{\circ} \mathrm{C}$ (Table 3), which was expected and support fishery activities. Fish could grow well in the water temperature range of $25-32^{\circ} \mathrm{C}$ in tropical waters [18]. The water transparency ranged from 90-160 cm (Table 3). The lowest transparency was usually found in the inlet reservoir area because the flow carried sediment particles before settling. In general, the transparency of the reservoir waters can support the life of tilapia, which was currently widely cultivated in that reservoir.

The dissolved oxygen was an important parameter because it was related to the respiration process of aquatic organisms. The dissolved oxygen ranged from 0 to $8.79 \mathrm{mg} / \mathrm{l}$ (Table 4). The lowest oxygen concentration was found at the Jatiluhur Reservoir inlet (ST I), also the Cirata reservoir outlet. Cirata Reservoir was one of the cascading reservoirs in the Citarumriver, located above Jatiluhur Reservoir. Cirata Reservoir had more floating cage activities than Jatiluhur Reservoir. The water that flowed out from the outlet of the Cirata reservoir commonly has hypoxia conditions. The concentration of BOD was widely used to determine the level of water pollution. If the BOD concentration was high, it could threaten aquatic biota life because of decreased dissolved oxygen concentration. It could be a medium for disease spread also (24). The BOD was 1.60 - $15.21 \mathrm{mg} / \mathrm{l}$ (Table 4). Those that had exceeded the threshold that occurred in September were presumed it was a dry season with less water volume so that the organic contamination material was concentrated.

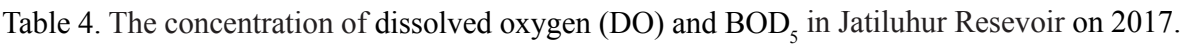

\begin{tabular}{|c|c|c|c|c|c|c|c|c|c|c|}
\hline Month & Parameters & ST 1 & ST 2 & ST 3 & ST 4 & ST 5 & ST 6 & ST 7 & ST 8 & ST 9 \\
\hline \multirow{3}{*}{ February } & DO (mg/l) & 1.53 & 2.56 & 2.45 & 2.75 & 1.84 & - & 3.43 & 8.79 & 2.54 \\
\cline { 2 - 11 } & BOD5 (mg/l) & 3.15 & - & 2.89 & 4.94 & - & - & 4.94 & 6.31 & - \\
\hline \multirow{3}{*}{ March } & DO (mg/l) & 0.00 & 2.36 & 2.01 & 3.92 & 2.49 & 5.90 & 2.50 & 5.06 & 5.94 \\
\cline { 2 - 11 } & BOD5 (mg/l) & 8.30 & 18.50 & 4.21 & 2.61 & 3.89 & 2.40 & 1.92 & 3.60 & 3.14 \\
\hline \multirow{3}{*}{ August } & DO (mg/l) & 0.33 & 0.28 & 2.55 & 3.98 & 2.22 & 4.70 & 2.86 & 5.49 & 4.81 \\
\cline { 2 - 11 } & BOD5 (mg/l) & 3.20 & 3.56 & 2.27 & 3.71 & 5.77 & 4.95 & 5.93 & 6.96 & 5.67 \\
\hline \multirow{3}{*}{ September } & DO (mg/l) & 1.03 & 1.69 & 2.80 & 4.51 & 2.98 & 4.06 & 2.56 & 5.94 & 4.33 \\
\cline { 2 - 10 } & BOD5 (mg/l) & 10.00 & 7.52 & 8.11 & 8.21 & 4.80 & 5.23 & 6.94 & 15.21 & 10.94 \\
\hline \multirow{2}{*}{ October } & DO (mg/l) & 2.24 & 1.49 & 2.31 & 2.94 & 2.45 & 3.18 & 1.93 & 4.39 & 4.86 \\
\cline { 2 - 10 } & BOD5 (mg/l) & 1.60 & 5.44 & 6.64 & 5.98 & 5.71 & 2.72 & 2.24 & 1.76 & 2.19 \\
\hline
\end{tabular}

Note: Standard of dissolved oxygen is $4 \mathrm{mg} / \mathrm{L}$ dan $\mathrm{BOD}_{5}$ is $3 \mathrm{mg} / \mathrm{l}$ based on second class quality standards of Government Regulation No 82 Year 2001 
Table 5. The concentration of orthophosphate and total phosphorus in Jatiluhur Resevoir on 2017.

\begin{tabular}{|c|c|c|c|c|c|c|c|c|c|c|}
\hline Month & Parameters & ST 1 & ST 2 & ST 3 & ST 4 & ST 5 & ST 6 & ST 7 & ST 8 & ST 9 \\
\hline \multirow{3}{*}{ February } & Orthophosphate $(\mathrm{mg} / \mathrm{l})$ & 0.045 & $<0.003$ & 0.003 & 0.003 & 0.006 & - & 0.028 & 0.015 & 0.010 \\
\cline { 2 - 10 } & Total phosphorus $(\mu \mathrm{g} / \mathrm{l})$ & 77 & 40 & 57 & 67 & 63 & - & 50 & 50 & 37 \\
\hline \multirow{3}{*}{ March } & Orthophosphate $(\mathrm{mg} / \mathrm{l})$ & 0.018 & 0.009 & 0.003 & 0.005 & $<0.003$ & $<0.003$ & $<0.003$ & $<0.003$ & 0.003 \\
\cline { 2 - 10 } & Total phosphorus $(\mu \mathrm{g} / \mathrm{l})$ & 183 & 127 & 120 & 100 & 50 & - & 50 & 75 & 75 \\
\hline \multirow{3}{*}{ August } & Orthophosphate $(\mathrm{mg} / \mathrm{l})$ & 0.081 & 0.030 & $<0.003$ & $<0.003$ & $<0.003$ & 0.006 & 0.003 & 0.003 & $<0.003$ \\
\cline { 2 - 10 } & Total phosphorus $(\mu \mathrm{g} / \mathrm{l})$ & 2,723 & 1,420 & 683 & 450 & 577 & 687 & 750 & 1,090 & 493 \\
\hline \multirow{3}{*}{ September } & Orthophosphate $(\mathrm{mg} / \mathrm{l})$ & 0.044 & 0.046 & 0.006 & 0.003 & 0.005 & 0.003 & 0.004 & 0.017 & 0.007 \\
\cline { 2 - 10 } & Total phosphorus $(\mu \mathrm{g} / \mathrm{l})$ & 1,737 & 1,185 & 637 & 400 & 1,403 & 1,457 & 467 & 2,170 & 357 \\
\hline \multirow{2}{*}{ October } & Orthophosphate $(\mathrm{mg} / \mathrm{l})$ & 0.098 & 0.031 & 0.004 & $<0.003$ & 0.021 & $<0.003$ & $<0.003$ & 0.004 & $<0.003$ \\
\cline { 2 - 10 } & Total phosphorus $(\mu \mathrm{g} / \mathrm{l})$ & 1,580 & 1,640 & 1,960 & 3,217 & 2,510 & 3,253 & 1,420 & 870 & 1,587 \\
\hline
\end{tabular}

Note: The standard of total phosphorus is $100 \mu \mathrm{g} / \mathrm{l}$ based on the Minister of Environment Decree No. 28 Year 2009

The orthophosphate concentration ranged from $<0.003$ to $0.098 \mathrm{mg} / 1$, and total phosphorus concentration ranged from 56 to $3,253 \mu \mathrm{g} / 1$ (Table 5). Total phosphorus had exceeded the quality standard. The source of phosphorus was from aquaculture activities by floating cages and the inlet of the reservoir. Carp and tilapia need feed contained phosphorus about $0.6-0.7 \%$ and $0.8-1.0 \%$, respectively, while the phosphorus content of fish feed could reach 1.27-1.66\% $(1.50 \%)$, so that some would be excreted [19].

In general, the fish feed contained protein, fat, and carbohydrates, which were composed of nitrogen and phosphate elements with a composition of 24$26 \%$ nitrogen and $0.96 \%$ phosphate [20]. Floating cage activities also influenced the phosphorus concentration in the Jatiluhur reservoir in Cirata Reservoir, which had a eutrophic level and it was the main water source for that reservoir [21; 22]. The phosphorus load could settle on sediment, but about $60 \%$ can re-suspend to the water column [7]. High phosphorus indicated contamination of organic matter and was an indicator of eutrophication.

Nitrate was necessary for the growth of phytoplankton and aquatic plants. The nitrate concentration was 0.071-3.023 mg/l (Table 6), and it was still below the standard value. Nitrite resulted from the nitrification process, and it was toxic to organisms, including aquatic fauna. The nitrite concentration was $<0.001-0.049 \mathrm{mg} / \mathrm{l}$ (Table 6), which meant it was still below the standard value.

Chlorophyll-a was a pigment used to determine phytoplankton biomass as a bioindicator in aquatic ecosystems [2]. Chlorophyll-a in phytoplankton played a role in the photosynthesis process in water. Chlorophyll-a could estimate water productivity and water quality monitoring and guide environmental protection and fishing areas. If its content was

Table 6. The concentration of nitrite and nitrate in Jatiluhur Resevoir on 2017.

\begin{tabular}{|c|c|c|c|c|c|c|c|c|c|c|}
\hline Month & Parameters & ST 1 & ST 2 & ST 3 & ST 4 & ST 5 & ST 6 & ST 7 & ST 8 & ST 9 \\
\hline \multirow{3}{*}{ February } & Nitrit (mg/l) & 0.004 & - & 0.009 & 0.013 & 0.011 & - & 0.019 & 0.046 & 0.011 \\
\cline { 2 - 10 } & Nitrat (mg/l) & 0.081 & - & 0.306 & 0.274 & 0.701 & - & 1.084 & 0.385 & 0.407 \\
\hline \multirow{3}{*}{ March } & Nitrit (mg/l) & 0.002 & 0.001 & 0.001 & 0.001 & 0.001 & 0.001 & 0.002 & 0.001 & 0.001 \\
\cline { 2 - 10 } & Nitrat (mg/l) & 0.090 & 0.105 & 0.093 & 0.097 & 0.189 & 0.078 & 0.211 & 0.076 & 0.071 \\
\hline \multirow{3}{*}{ August } & Nitrit (mg/l) & 0.002 & 0.001 & 0.002 & 0.001 & 0.015 & 0.001 & 0.006 & 0.013 & 0.001 \\
\cline { 2 - 10 } & Nitrat (mg/l) & 0.737 & 0.820 & 0.968 & 0.867 & 1.312 & 1.810 & 0.931 & 3.023 & 1.779 \\
\hline \multirow{3}{*}{ September } & Nitrit (mg/l) & 0.001 & 0.001 & 0.002 & 0.001 & $<0.001$ & $<0.001$ & 0.004 & 0.004 & $<0.001$ \\
\cline { 2 - 10 } & Nitrat (mg/l) & 0.911 & 0.876 & 1.252 & 1.363 & 1.030 & 1.065 & 1.065 & 0.404 & 0.589 \\
\hline \multirow{2}{*}{ October } & Nitrit (mg/l) & 0.005 & 0.004 & 0.007 & 0.002 & 0.006 & 0.003 & 0.011 & 0.049 & 0.002 \\
\cline { 2 - 9 } & Nitrat (mg/l) & 0.318 & 0.322 & 0.179 & 0.286 & 0.202 & 0.253 & 0.263 & 0.446 & 0.231 \\
\hline
\end{tabular}

Note: Standard of nitrate is $10 \mathrm{mg} / \mathrm{l}$ dan nitrite is $0.06 \mathrm{mg} / \mathrm{l}$ based on second class quality standards of Government Regulation No 82 Year 2001 
Table 7. The concentration of chlorophyll-a $(\mu \mathrm{g} / \mathrm{l})$ in Jatiluhur reservoir in Jatiluhur Resevoir on 2017.

\begin{tabular}{|c|c|c|c|c|c|c|c|c|c|}
\hline Month & ST 1 & ST 2 & ST 3 & ST 4 & ST 5 & ST 6 & ST 7 & ST 8 & ST 9 \\
\hline February & 2.685 & 7.2124 & 14.619 & 7.849 & 7.141 & - & 4.741 & 13.217 & 11.668 \\
\hline March & 6.746 & 19.115 & 22.297 & 15.741 & 13.866 & 10.329 & 7.956 & 10.331 & 10.08 \\
\hline August & 2.431 & - & 9.623 & 14.604 & 14.171 & 16.607 & 8.068 & 1.825 & 17.517 \\
\hline September & 9.040 & 25.304 & 11.141 & 15.439 & 4.213 & 6.380 & 11.852 & 8.082 & 7.405 \\
\hline October & 6.189 & 5.370 & 45.027 & 17.520 & 12.899 & 15.789 & 14.603 & 12.842 & 20.694 \\
\hline
\end{tabular}

excessive, it was indicating a process of eutrophication [26]. The chlorophyll-a concentration ranged from 1.825 to $45.027 \mu \mathrm{g} / \mathrm{l}$ (Table 7). It was indicating a eutrophication process in Jatiluhur Reservoir. The chlorophyll-a concentration was $>10 \mathrm{mg} / \mathrm{m}^{3}$ indicated waters at a eutrophic level [27]. The average value of chlorophyll-a concentration was smaller than $18.37 \mu \mathrm{g} / 1$ in the Kedung Ombo Reservoir [28].

\section{Eutrophication Level}

Based on the Trix and TSI index analysis, the eutrophication level in Jatiluhur Reservoir was at the eutrophic-hypereutrophic level. Completed Trix dan TSI index was presented in Table 8.

Eutrophication had caused ecological, social, and economic problems such as uncontrolled algae growth, oxygen depletion, damage to freshwater ecosystems, and incompatibility of water use for humans [29]. In 1981, Jatiluhur Reservoir had an oligotrophic level, then in 1988 increased to mesotrophic [6]. In 1991, it turned into oligotrophic-mesotrophic, namely in the initial inundation of the Cirata and Saguling reservoirs, which were upper of these cascade reservoir systems [30]. In 2004, it increased to be eutrophic, and then in 2006, it had become hypereutrophic [7]. In 2017, its status changed again to eutrophic-hypereutrophic. This trophic status increase was in line with the increasing number of floating cages in Cirata and Jatiluhur reservoirs, which have an over-carrying capacity. Based on the Decree of the Governor of West Java No 660.31/ Kep.923.DKP/2019 stated that the carrying capacity of the Cirata reservoir was 7,204 plots, and the Jatiluhur reservoir was 11,306 plots. However, currently, the number of floating cages in Cirata was nearly 90,000, and Jatiluhur Reservoir reached 45,000 plots.

Several lakes or reservoirs in Indonesia which had experienced eutrophication were: the eutrophic level based on TSI (58.37-61.51) and Trix (4.62-5.32) at Situ Lido, Bogor [31], the eutrophic level based on TSI (56.16-63.40) [21] and Trix (5-6) and TSI (77.6-79.5) at Cirata Reservoir, West Java [32], the eutrophic level based on Trix (5.35-5.70) at Kedung Ombo Reservoir, Central Java [28], the hypereutrophic level based on Trix (4.88-6.32) at Panglima Besar Sudirman Reservoir, Central Java [33], the eutrophic-hypertrophic level based on transparency $(85-94 \mathrm{~cm})$; total P $(18-249 \mu \mathrm{g} / \mathrm{l})$ and chlorophyll a (0.581-14 $\mu \mathrm{g} / \mathrm{l})$ at Ir. Sutami Reservoir, Malang [34], the eutrophic level based on TSI (53.55-66.74) at Sempor Reservoir, Kebumen [35], the eutrophic-hypertrophic based on chlorophyll a (0.93-27.01 $\mu \mathrm{g} / \mathrm{l})$ at Lake Tondano, North Sulawesi [36], and the eutrophic level based on TSI (53.79-58.59) at Wonorejo Reservoir. Tulung Agung [37].

The-classes, number of species, and phytoplankton species data were presented in Tables 9 and 10. Based on the results of phytoplankton identification from the observed samples, a total of 50 phytoplankton species

Table 8. The eutrophication level in Jatiluhur Reservoir based on Trix and TSI Index on 2017.

\begin{tabular}{|c|c|c|c|c|c|c|c|c|c|c|c|}
\hline \multirow{2}{*}{ Month } & Index & ST 1 & ST 2 & ST 3 & ST 4 & ST 5 & ST 6 & ST 7 & ST 8 & ST 9 & Criteria \\
\hline \multirow{3}{*}{ February } & Trix & 6.99 & - & 5.83 & 4.65 & 6.03 & - & 7.09 & 5.77 & 6.02 & E-HE \\
\cline { 2 - 14 } & TSI Index & 54.35 & 56.39 & 59.51 & 56.19 & 53.17 & - & 50 & 60.43 & 53.80 & E \\
\hline \multirow{3}{*}{ March } & Trix & 5.93 & 6.61 & 6.21 & 6.45 & 5.92 & 5.34 & 6.63 & 6.01 & 5.4 & E-HE \\
\cline { 2 - 14 } & TSI Index & 62.82 & 62.82 & 62.72 & 60.39 & 55.96 & 55.78 & 56.12 & 65.47 & 57.72 & E \\
\hline \multirow{2}{*}{ August } & Trix & 5.09 & 5.38 & 5.57 & 6.24 & 5.39 & 5.68 & 6.76 & - & 5.27 & E-HE \\
\cline { 2 - 14 } & TSI Index & 69.96 & 76.96 & 67.83 & 67.86 & 69.11 & 72.03 & 68.80 & 74.8 & 69.66 & E-HE \\
\hline \multirow{2}{*}{ September } & Trix & 6.58 & 5.24 & 5.68 & 4.35 & 5.62 & 5.04 & 5.32 & - & 5.81 & E-HE \\
\cline { 2 - 13 } & TSI Index & 76.80 & 79.71 & 70.37 & 67.58 & 67.82 & 69.86 & 68.20 & 81.13 & 65.05 & E-HE \\
\hline \multirow{2}{*}{ October } & Trix & - & - & 6.83 & 5.2 & 5.76 & 5.67 & 7.07 & - & 5.34 & E-HE \\
\cline { 2 - 12 } & TSI Index & 78.73 & 80.39 & 80.54 & 79.82 & 75.75 & 79.28 & 73.02 & 73.09 & 76.86 & E-HE \\
\hline
\end{tabular}

Remarks: E-HE = eutrophic-hypertrophic; E = eutrophic 
Table 9. The number of phytoplankton species found during the month of observation.

\begin{tabular}{|c|c|c|c|c|c|c|}
\hline \multirow{2}{*}{ Class of Phytoplankton } & \multicolumn{7}{|c|}{ Month } & \multirow{2}{*}{ Average } \\
\cline { 2 - 7 } & February & March & August & September & October \\
\hline Bacillariophyceae & 2 & 2 & 7 & 3 & 3 & 3 \\
\hline Cholorphyceae & 23 & 21 & 24 & 21 & 20 & 22 \\
\hline Cyanophyceae & 7 & 5 & 7 & 7 & 6 & 6 \\
\hline Dinophyceae & 2 & 2 & 2 & 3 & 2 & 2 \\
\hline Euglenaphyceae & 3 & 1 & 3 & 3 & 3 & 3 \\
\hline
\end{tabular}

were found. These species are classified into five classes, with the number of species 37 species, 31 species, 43 species, 37 species, and 34 species found in February, March, August, September, and October, respectively. Almost all phytoplankton species were found every month during the observation. The phytoplankton species that dominate every month are Ankistrodesmus $\mathrm{sp}$, Chlorella sp, Closterium sp, Cosmarium sp, Crucigenia sp, Euastrum sp, Oocystis sp. Pandorina sp. Pediastrum sp. Radiococcus sp. Raphidiopsis sp. and Scenedesmus sp from the class Chlorophyceae, Lyngbya sp. Merismopedia sp. Microcystis sp. Oscilatoria sp. from the class Cyanophyceae, and Ceratium sp and Peridinium sp from class Dinophyceae.

The abundance of phytoplankton at nine stations (Table 11) was shown a relatively high difference. In February, the station with the highest total abundance was $559 \times 10^{3}$ cells/litre at ST 3, and the lowest was
$10 \times 10^{3}$ cells/litre at station ST 1. In March, the highest abundance was $117 \times 10^{4}$ cells/litre at station ST 3, and the lowest was $6.3 \times 10^{3}$ cells/litre at station ST 1 . In August, the highest abundance occurred at station ST 9 with an abundance of $34 \times 10^{3}$ cells/litre, the lowest abundance occurred at station ST 1 with $6.3 \times 10^{3}$ cells/litre. In September, the highest of phytoplankton abundance increased became $1505 \times 10^{3}$ cells/litre occurring at station ST 9 and the lowest abundance was $90 \times 10^{3}$ cells/litre at station ST 1 . In October, the highest abundance of phytoplankton was $407 \times 10^{3}$ cells/litre at station ST 9, and the lowest abundance was $59 \times 10^{3}$ cells/litre at station ST 1 .

An increase in eutrophication level was due to increased nitrogen, and phosphorus nutrients cause algae growth. It could even become blooming alga. The proportion of Cyanobacteria could increase along with the increase in nutrients and chlorophyll-a, indicated

Table 10. The distribution of phytoplankton species found during the month of observation.

\begin{tabular}{|c|c|c|c|c|c|}
\hline Class & \multicolumn{5}{|c|}{ Month } \\
\hline Species & February & March & August & September & October \\
\hline \multicolumn{6}{|l|}{ Bacillariophyceae } \\
\hline Coconeis sp. & & & + & + & \\
\hline Coscinodiscus sp. & & + & & & \\
\hline Cymbella sp. & & & + & & \\
\hline Navicula sp. & + & & + & & + \\
\hline Nitzschia sp. & & & + & + & + \\
\hline Pleurosigma sp. & & & + & & \\
\hline Synedra sp. & + & + & + & + & + \\
\hline Surirella sp. & & & + & & \\
\hline \multicolumn{6}{|l|}{ Chlorophyceae } \\
\hline Actinastrum sp. & + & & + & + & + \\
\hline Ankistrodesmus sp. & + & + & + & + & + \\
\hline Chlorella sp. & + & + & + & + & + \\
\hline Chlorogonium sp & & & + & + & + \\
\hline Chrococcus sp. & + & + & + & + & \\
\hline
\end{tabular}


Table 10. Continued.

\begin{tabular}{|c|c|c|c|c|c|}
\hline Closterium sp. & + & + & + & + & + \\
\hline Coelastrum sp. & + & + & + & + & \\
\hline Cosmarium sp. & + & + & + & + & + \\
\hline Crucigenia sp. & + & + & + & + & + \\
\hline Dictyosphaerium sp. & + & + & + & & + \\
\hline Errerella sp. & + & & + & + & \\
\hline Eudorina $\mathrm{sp}$. & + & + & & & \\
\hline Euastrum sp. & + & + & + & + & + \\
\hline Oocystis sp. & + & + & + & + & + \\
\hline Pandorina sp. & + & + & + & + & + \\
\hline Pediastrum sp. & + & + & + & + & + \\
\hline Radiococcus sp. & + & + & + & + & + \\
\hline Raphidiopsis sp. & + & + & + & + & + \\
\hline Scenedesmus sp. & + & + & + & + & + \\
\hline Selenastrum sp. & + & & + & & \\
\hline Sorastrum sp. & & & & & + \\
\hline Sphaerocystis sp. & + & & & + & + \\
\hline Spyrogira sp. & & & + & & \\
\hline Staurastrum sp. & + & + & + & + & + \\
\hline Staurodesmus sp. & & + & & & \\
\hline Treubaria sp. & + & + & + & + & + \\
\hline Tribonema sp. & + & + & . & & + \\
\hline Ulothrix sp. & & & + & & \\
\hline Zygnema sp. & & + & & & \\
\hline \multicolumn{6}{|l|}{ Cyanophyceae } \\
\hline Acanthoceras sp. & + & . & + & + & + \\
\hline Anabaena sp. & + & + & + & + & + \\
\hline Gleocystis sp. & & & + & & \\
\hline Lyngbya sp. & + & + & + & + & + \\
\hline Merismopedia sp. & + & + & + & + & + \\
\hline Microcystis sp. & + & + & + & + & + \\
\hline Oscilatoria sp. & + & + & + & + & + \\
\hline Spirulina sp. & + & & & + & \\
\hline \multicolumn{6}{|l|}{ Dinophyceae } \\
\hline Ceratium sp. & + & + & + & + & + \\
\hline Peridinium sp. & + & + & + & + & + \\
\hline \multicolumn{6}{|l|}{ Euglenophyceae } \\
\hline Euglena sp. & + & & + & + & + \\
\hline Phacus sp. & + & & + & + & + \\
\hline \multirow[t]{2}{*}{ Trachelomonas sp. } & + & + & + & + & + \\
\hline & 37 & 31 & 43 & 37 & 34 \\
\hline
\end{tabular}


Table 11. Average of phytoplankton species at Jatiluhur Reservoir on 2017.

\begin{tabular}{|c|c|c|c|c|c|c|c|c|c|}
\hline \multirow{2}{*}{ Month } & \multicolumn{7}{|c|}{ Average of phytoplankton abundance (cells/litre) } \\
\cline { 2 - 10 } & ST 1 & ST 2 & ST 3 & ST 4 & ST 5 & ST 6 & ST 7 & ST 8 & ST 9 \\
\hline February & $10 \times 10^{3}$ & $498 \times 10^{3}$ & $559 \times 10^{3}$ & $504 \times 10^{3}$ & $259 \times 10^{3}$ & $239 \times 10^{4}$ & $130 \times 10^{3}$ & $184 \times 10^{3}$ & $193 \times 10^{3}$ \\
\hline March & $6.3 \times 10^{3}$ & $122 \times 10^{3}$ & $117 \times 10^{4}$ & $106 \times 10^{3}$ & $246 \times 10^{3}$ & $178 \times 10^{3}$ & $127 \times 10^{3}$ & $74 \times 10^{3}$ & $156 \times 10^{3}$ \\
\hline August & $6.3 \times 10^{3}$ & $7 \times 10^{3}$ & $13 \times 10^{3}$ & $25 \times 10^{3}$ & $25 \times 10^{3}$ & $32 \times 10^{3}$ & $10 \times 10^{3}$ & $18 \times 10^{3}$ & $34 \times 10^{3}$ \\
\hline September & $90 \times 10^{3}$ & $1002 \times 10^{3}$ & $527 \times 10^{3}$ & $740 \times 10^{3}$ & $497 \times 10^{3}$ & $926 \times 10^{3}$ & $856 \times 10^{3}$ & $631 \times 10^{3}$ & $1505 \times 10^{3}$ \\
\hline October & $59 \times 10^{3}$ & $253 \times 10^{3}$ & $331 \times 10^{3}$ & $318 \times 10^{3}$ & $353 \times 10^{3}$ & $316 \times 10^{3}$ & $180 \times 10^{3}$ & $263 \times 10^{3}$ & $407 \times 10^{3}$ \\
\hline
\end{tabular}

that eutrophication and nutrient enrichment trigger an increase in Cyanobacteria and cause become dominant in the composition of phytoplankton [38]. Some factors, i.e., weather conditions, activities around the waters, and changes in the aquatic environmental quality, could also influence the variation of phytoplankton abundance. In Lake Rawa Pening, phytoplankton in the cage area was dominated by Peridinium cinctum, followed by Synedra ulna, whereas non-cage areas dominated by Peridinium cinctum, Haematococcus pluvialis, and Aulacoseira granulata [39]. The abundance of phytoplankton found in the Wonorejo Reservoir ranged from 19,500 to 159,750 cells $/ \mathrm{ml}$, so that reservoir was in eutrophic waters [37].

\section{Some Recommendations for Eutrophication Control in Jatiluhur Reservoir}

The results show that the Jatiluhur reservoir was already on a eutrophic-hypertrophic level. One of the symptoms that appeared was the high abundance of phytoplankton with several genera. The growth of phytoplankton was supported by increasing $\mathrm{N}$ and $\mathrm{P}$ nutrients, which were macro and essential nutrients for phytoplankton's growth. Loading of phosphorus pollution came from internal source as floating net cage and external source like a river. Internal loading of phosphorus from floating net cage about 2,382.9 ton/yr and external loading from rivers reached 11,091.5 ton/yr [46]. The disadvantages of the high level of eutrophication were: the high phytoplankton abundance, the dominance of plankton, and the blooming of aquatic plants. These phenomenons could be caused by oxygen depletion and disturbed the view of the waterscape aesthetically.

Controlling the level of eutrophication is an effort to manage waters so that there was an ecological balance. Some efforts to control eutrophication that could be recommended were:

1. We could utilize aquatic macrophytes as an agent for utilizing excess nitrogen and phosphorus. In China, floating and submerged macrophytes had used for eutrophication control and recovery at a low cost. Examples of macrophytes used to improve eutrophication rates in China were: water hyacinth, elephant grass, cat's tail, and canna. These plants could absorb nitrogen and phosphorus during their growing, inhibited algae growth by competing for sunlight and nutrients. Their root systems also provided specific habitats for aerobic and anaerobic bacteria. Application in Lake Donghu could reduce phosphorus and nitrogen nutrients and increase transparency [40].

2. We could be stocking planktivore fishes such as milkfish (Chanos chanos), silver carp (Hypophthalmichthys molitrix), and silver barb (Barbonymus gonionotus). The fish-stocking must pay attention to community preferences for fish commodities [41]. The effort of Culture-Based Fisheries (CBF) could be initiated where CBF itself was a kind of fish resource recovery technology that could be applied to the waters where fish production had decreased and had moderate to high trophic levels [42].

3. We could apply environmentally-friendly fish farming activities in floating cages, such as the recommendation from [43]. The floating cage system with a water management system through recirculation and plants could reduce the burden of organic pollution from wasted feed and fish excretion. This system adopted a modified aquaponic system so that it can be applied in open water. In this system, the remaining feed and the fish excretion were accommodated with a waterproof layer and then removed by sweeping and pumping [44].

Simulation [7], through dynamic modelling, stated that control and restoration of eutrophication in reservoirs must be integrated. It was done through a combination of reducing the external nutrient load by up to $90 \%$ and managing the internal reservoir environment. Thus, the potential growth of phytoplankton could be reduced by almost $50 \%$ of the current amount. This integrated control hoped that the abundance of phytoplankton in the Jatiluhur Reservoir could be reduced to below $1 \times 10^{4}$ individuals/litre.

\section{Conclusions}

Based on the trophic state index value of Carlson, Trix, and the abundance of phytoplankton, the Jatiluhur Reservoir had a trophic status in the level of eutrophic- 
hypertrophic. It was characterized by high chlorophyll-a and total phosphorus. Alternative management of the Jatiluhur Reservoir to control eutrophication can be done by (1) utilizing macrophytes as an agent for reducing phosphorus and nitrogen nutrients, (2) planktivorous fish stocking, and (3) implementing an environmentally friendly fish culture system.

\section{Acknowledgments}

The authors are grateful to the Research Institute for Fish Resource Enhancement, Ministry of Marine Affairs and Fisheries Republic of Indonesia for funding through the research program titled: Fish Population Recovery and Environmental Rehabilitation in Ir. H. Djuanda, Purwakarta on Fiscal Year 2017 Budget Year. Each author was a primary contributor to this article.

\section{Conflict of Interest}

The authors declare that they have no conflict of interest. The authors confirmed that the data and the paper are free of plagiarism.

\section{References}

1. KAFF M.A. Eutrophication in shallow lakes and water dams. A Magazine for the Environmental Centre for Arab Towns. Issue $2^{\text {nd }}$ ed. 2012

2. LIU W., LI S., BU H., ZHANG Q., LIU G. Eutrophication in the Yunnan Plateau lakes: the influence of lake morphology, watershed land use, and socioeconomic factors. Environ. Sci. Pollut. Res.19, 858, 2012.

3. HENDERSON-SELLERS B., MARKLAND H.R. Decaying lake the origin and control of cultural eutrophication. John Wiley \& Sons, Inc.: Chichester, West Sussex, NY, 254, 1987.

4. SUDJANA T. Perum Jasa Tirta II Policy in Reservoir Management and Utilization Ir. $\mathrm{H}$ Djuanda for Aquaculture. Proceedings of Development of Aquaculture in Reservoir.Aquaculture Research Center: Jakarta, Indonesia, 2004 [In Indonesian].

5. GAL D., KUCSKA B., KEREPECZKI E., GYALOG G. Feasibility of the sustainable freshwater cage culture in Hungary and Romania. AACL Bioflux, 4 (5), 598, 2011.

6. NURONIAH S., KARTAMIHARDJA E.S..Preliminary study of primary productivity in Jatiluhur Reservoir, West Java. Buletin Penelitian Perikanan Darat, 22, 1988 [In Indonesian].

7. IRIANTO E.W., TRIWEKO R.W., YUDIANTO D. Long term dynamic estimation of water quality for eutrophication control in Jatiluhur Reservoir. Jurnal Teknik Hidraulik, 3 (1), 1, 2012 [In Indonesian].

8. CARLSON R.E. A trophic state index for lakes. Limnology and Oceanography, 22 (2), 361, 1977.

9. PRIMPAS I., KARYDIS M. Scaling the trophic index (TRIX) in oligotrophic marine environments. Environmental Monitoring and Assessment, 178, 257, 2011.
10. WHIPPLE G.C. The microscopy of drinking water. John Wiley \& Sons, Inc.: London, 586, 1947.

11. EDMONSON W.T. Freshwater Biology. $2^{\text {nd }}$ Ed. John Wiley \& Sons, Inc.: New York, 1248, 1978.

12. NEEDHAM J.G., NEEDHAM P.R. A Guide to the Study of Freshwater Biology. $5^{\text {th }}$ Edition. Revised and Enlarged. Holden Day Inc: San Fransisco, 180, 1963.

13. SACHLAN M. Planktonologi. Correspondence Course Centre. Agriculture Ministry: Jakarta, Indonesia, 141, 1982 [In Indonesian].

14. JI Z.G. Hydrodynamics and Water Quality: Modelling Rivers, Lakes, and Estuaries. Wiley Interscience: Canada, 2008.

15. VOLLENWEIDER R.A., GIOVANARDI F., MONTANARI G., RINALDI A. Characterization of the trophic conditions of marine coastal waters with special reference to the N.W. Adriatic Sea. Proposal for a trophic scale, turbidity and a generalized water quality index. Environmetrics, 9, 329, 1998.

16. LI S.F. Fish Culture in Cages and Pens. In Freshwater Fish Culture in China: Principles and Practice. Elsevier: Amsterdam, Nederland, 305. 1994.

17. SUTADIAN A.H., MUTTI N., YILMAZ A., PERERA C. Development of river water quality indices - a review. Environmental Monitoring and Assessment, 188, 58, 2016.

18. BOYD C.E. Water quality in ponds for aquaculture. Auburn University of Agriculture Experiment Station: Alabama, USA, 359, 1990.

19. ARDI I. Aquaculture system with floating net cages in order to maintain the environmental sustainability of Cirata Reservoir waters. Media Akuakultur, 8 (1), 23, 2013 [In Indonesian].

20. HUSSEIN M.S. Effect of various feeding frequencies on growth performance and previously starved fingerlings and juveniles of African catfish (Clarias gariepinus). Egypt. J. Aquat. Biol. Fish, 16 (2), 145, 2012.

21. ARIYANI M., AGUSTIAN M., MAHARANI G.S., SUNARDI. Assessment of seasonal trophic state of tropical man-made lake, The Cirata Reservoir. In IOP Conf. Series: Earth and Environmental Science 277 012030. IOP Publishing. 2019.

22. PURNAMANINGTYAS S.E., TJAHJO D.W.H Monitoring of water quality to support fisheries in Cirata Reservoir, West Java. Jurnal Penelitian Perikanan Indonesia, 14 (2), 173, 2008 [In Indonesian]

23. ZUMMI N.Z., ASTRIYANI R.N., SUHARIANTO. Analysis of river water quality conformity with water quality standards for freshwater fish cultivation in Tabalong Regency. SPECTA Journal of Technology, 3 (3), 36, 2019 [In Indonesian].

24. TAMYIZ M. Comparison of the ratio of BOD / COD in the pond area upstream and downstream to the biodegradability of organic matter. Journal of Research and Technology, 1 (1), 9, 2015 [In Indonesian].

25. PICADO A., ALVAREZ I., VAZ N., VARELA R., GOMEZ-GESTEIRA M., DIAS J.M. Assessment of chlorophyll variability along the northwestern coast of Iberian Peninsula. Journal of Sea Research, 93, 2, 2014.

26. MASLUKAH L., ZAINURI M., WIRASATRIYA A., SALMA U. Spatial Distribution of Chlorophyll-a and Its Relationship with Dissolved Inorganic Phosphate Influenced by Rivers in the North Coast of Java. Journal of Ecological Engineering, 20 (7), 18, 2019.

27. NOVOTNY V., OLEM H. Water quality, prevention, identification, and management of diffuse pollution. Van Nostrans Reinhold: New York, 1054, 1994. 
28. AIDA S.N., UTOMO A.D. Trophic status of Kedung Ombo Reservoir in Central Java. BAWAL, 4 (1), 59, 2012 [In Indonesian].

29. ZHANG W., JIN X., LIU D., LANG C., SHAN B. Temporal and spatial variation of nitrogen and phosphorus and eutrophication assessment for a typical arid riverFuyang River in northern China. Journal of Environmental Sciences, 55, 41, 2017.

30. SUKIMIN S., NURLATIFAH H. Citarum cascade reservoir fishery management. Prosiding Semiloka Nasional Pengelolaan dan Pemanfaatan Danau dan Waduk. Padjadjaran University: Bandung, Indonesia, 284, 2000 [In Indonesian].

31. PRATIWI N.T.M., HARIYADI S., AYU I.P., ISWANTARI A., AMALIA F.J. Phytoplankton composition and water trophic status of Lake Lido, Bogor-West Java through several approaches. Jurnal Biologi Indonesia, 9 (1), 111, 2013 [In Indonesian].

32. PRATIWI N.T.M., HARIYADI S., SOEGESTY N.B., WULANDARI D.Y.. Trophic status determination based on several approaches (case study: Cirata Reservoir). Jurnal Biologi Indonesia, 16 (1), 89, 2020 [In Indonesian].

33. WIDYASTUTI E., SUKANTO SETYANINGRUM N. Effect of organic waste on tropical status, N/P ratio and abundance of phytoplankton in Panglima Besar Soedirman Reservoir, Banjarnegara Regency. Biosfera, 32 (1), 35, 2015 [In Indonesian].

34. JUANTARI G.Y., SAYEKTI R.W., HARISUSENO D. Trophic status and pollution load capacity of the Sutami Reservoir. Jurnal Teknik Pengairan, 4 (1), 61, 2013 [In Indonesian].

35. SHALEH F.R., SOEWARDI K., HARIYADI S. Water quality and trophic status in Sempor Reservoir, Kebumen. Jurnal Ilmu Pertanian Indonesia, 19 (3), 169, 2014 [In Indonesian].

36. SUDARMADJI WANTASEN S., SUPRAYOGI S. The impact of land use in the catchment area and utilization of lake waters on the eutrophication and sustainability of Lake Tondano, North Sulawesi Province. Prosiding Seminar Nasional Limnologi VI. Limnology Research Center, Indonesian Institute of Sciences: Bogor, Indonesia. 2012 [In Indonesian].
37. PERMANASARI S.W.A., KUSRIANI, WIDJANARKO P. Water trophic level in Wonorejo Reservoir in relation to fish potential. Journal of Fisheries and Marine Science, 1 (2), 88, 2017 [In Indonesian].

38. BOQIANG Q., GUANG G., WEI Z., YUNLIN Z., YUZHI S., XIANGMING T., HAI X., JIANMING D. Lake eutrophication and its ecosystem response. Chin. Sci.Bull., 58 (9), 961, 2013.

39. SAMUDRA S.R., SOEPROBOWATI T.R., IZZATI M. Composition, abundance and diversity of phytoplankton in Lake Rawa Pening, Semarang Regency. BIOMA, 15 (1), 6, 2013 [In Indonesian].

40. LIU W., QIU R. Mini-review Water eutrophication in China and the combating strategies. J. Chem. Technol. Biotechnol., 82, 781, 2007.

41. ASTUTI L.P., NURFIARINI A., SUGIANTI Y., WARSA A., RAHMAN A., HENDRAWAN A.L.S. Sustainable fisheries management in Jatiluhur Reservoir. Dee Publisher: Yogyakarta, Indonesia. 260, 2016 [In Indonesian].

42. AISYAH, TRIHARYUNI S., PRIANTO E., PURWOKO R.M., HUSNAH. Culture-Based Fisheries (CBF) as an Effort to Increase Fish Production in Reservoirs. Jurnal Kebijakan Perikanan Indonesia, 11 (1), 53, 2019 [In Indonesian].

43. ASTUTI L.P., HENDRAWAN A.L.S., KRISMONO. Water quality management through application of smart cage culture. Jurnal Kebijakan Perikanan Indonesia, 10 (2), 87, 2018 [In Indonesian].

44. ASTUTI L.P., HENDRAWAN A.L.S., WARSA, A. Controlling pollution from floating cage culture in reservoir and lake using SMART-FCC system. In IOP Conference Series: Earth and Environmental Science 521. IOP Publishing. 2020.

45. AJI H.G.S. The evaluation of sedimentation rate in Jatiluhur Reservoir, Purwakarta. Bogor: Bogor Agricultural University, 2014 [In Indonesian].

46. ASTUTI L.P., TJAHJO D.W.H. Potential of phosphorus loads in Ir. H. Djuanda Reservoir at Purwakarta Regency, West Java. Bawal, 12 (1), 41-50, 2020 [In Indonesian]. 
